\title{
SIEF new working group on Museums and Material Culture
}

\author{
Hester Dibitis \& Lizette Gradén
}

A new working group was established at a conference held by the International Society for Ethnology and Folklore (SIEF) in Zagreb in June 2015. The group Museums and Material Culture is a platform for dialogue, cooperation, and networking among European ethnologists with a special interest in theorizing the field of museums and material culture. We hope this working group will be bridge-building also to our colleagues who are researchers and professionals currently not active in SIEF but whose active participation in the group would strengthen the Society and the discipline(s).

When ethnology evolved as a museum discipline in the late 19th century Europe, ethnologists' interpretations of material culture (local, rural, regional, folk) formed the collections at numerous museums. Museum collections played a significant role in the history of Europe. Since then, ethnologists have both shaped and reshaped the field of material culture studies and museum practice. However, the paths taken by the discipline of ethnology at the universities in Europe during the last 20 years have in many instances swayed away from the museum world. With a generational shift old perceptions have dissipated, and both museum professionals and academics can view the museum and processes of musealisation with fresh eyes and new perspectives.
The working group is a network and a digital platform connecting and reflecting on theory and practice. At the inaugural meeting in Zagreb in June 2015, participants suggested the following focus:

- How do museums produce knowledge?

- What is a museum today?

- How can museums contribute to current research?

More precisely the participants wanted the working group to be a network and digital platform facilitating:

- The development of joint research applications

- Cooperation between students, Ph.D.s, researchers

- Exchange of ideas for research and exhibition making

- Exchange of field work experiences

Over the next four years the working group proposes a focused initiative to:

- Convene at SIEF conferences

- Implement a series of professional activities

- Stimulate research in the field of material culture by drawing on the expertise of colleagues working in museums 
Finally, we will strive to:

1. Put together a working group with members from Europe and beyond.

2. Develop an electronic community of ethnologists in material culture in order to strengthen the communication and interaction among these scholars, curators, educators, administrators, digital asset managers etc. The working group is present on the SIEF website. A Facebook group was established June 2015.

3. As part of the community above, Museums and Material Culture is the name on the SIEF Website Wikipedia that will trace the contributions over time of European ethnologists' research of material culture in museums. This Wiki will include published works, projects, as well as policy work. The Wiki will be contingent on SIEF members' contributions.

4. Develop specific strategies to connect the SIEF working group with the International Council of Museums and the American Folklore Society Museum section.

5. Organize panels for SIEF's international congresses and workshops adjacent to these congresses.

6. Develop transnational projects to increase research on material culture and museums.

\section{Co-ChAIRS}

Hester Dibbits, Lector of cultural heritage and course director of the Master of Museology at Amsterdam University of the Arts (AHK) and endowed professor of historical culture and education at Erasmus University Rotterdam. hester.dibbits@ahk.nl

Lizette Gradén, Head of collections at the Royal Armoury and Skokloster Castle with the Hallwyl Museum and affiliate associate professor, Dept. of Scandinavian Studies, University of Washington.lizette.graden@lsh.se

\section{SECRETARY}

Uta Karrer, Ph.D. candidate, University of Basel uta.karrer@unibas.chor utakarrer@gmail.com 